\title{
Functional Equivalence of Created Wetland Water Quality: A Comparison of Amphibian Metamorphic Success
}

\author{
Lauren A. McPherson'1, Ida Holásková ${ }^{2}$, James T. Anderson ${ }^{1 *}$ \\ ${ }^{1}$ School of Natural Resources, West Virginia University, Morgantown, WV, USA \\ ${ }^{2}$ Office of Statistics, Davis College of Agriculture, Natural Resources and Design, West Virginia University, Morgantown, WV, USA \\ Email: *jim.anderson@mail.wvu.edu
}

How to cite this paper: McPherson, L.A., Holásková, I. and Anderson, J.T. (2020) Functional Equivalence of Created Wetland Water Quality: A Comparison of Amphibian Metamorphic Success. Open Journal of Ecology, 10, 418-439.

https://doi.org/10.4236/oje.2020.107027

Received: May 20, 2020

Accepted: June 26, 2020

Published: June 29, 2020

Copyright $\odot 2020$ by author(s) and Scientific Research Publishing Inc. This work is licensed under the Creative Commons Attribution International License (CC BY 4.0).

http://creativecommons.org/licenses/by/4.0/

\begin{abstract}
Wetlands are often created through wetland mitigation to replace lost natural wetlands, but further evaluation is needed to determine the ability of a created wetland to replace lost wetland functions, especially providing wildlife habitat. We used a mesocosm design to compare the water quality between three created wetlands and three natural wetlands in West Virginia, USA and to evaluate how the water quality from the two wetland types were able to support metamorphosis in larval spring peepers (Pseudacris crucifer) and wood frogs (Lithobates sylvaticus) across two years (2014-2015). Responses in metamorphosis rates differed between species and between years. Spring peepers displayed similar metamorphosis rates in the created and natural wetlands in both years of the study. Wood frogs displayed similar metamorphosis rates in created and natural wetlands in 2015, but in 2014 wood frogs reached metamorphosis in less time and at a larger body size in the natural wetlands, suggesting that the wood frogs that developed in the natural wetlands may have higher fitness than those that developed in the created wetlands. Water quality was largely similar between created and natural wetlands, although dissolved oxygen, conductivity, and $\mathrm{pH}$ varied between mesocosms and wetlands. Our study suggests that created wetlands may be providing partial mitigation in terms of water quality for amphibian development. We recommend that future monitoring of created wetlands include measures of juvenile amphibian recruitment as well as additional habitat variables to better determine the ability of created wetlands to function as amphibian habitat.
\end{abstract}

\section{Keywords}

Appalachians, Pseudacris crucifer, Spring Peeper, Lithobates sylvaticus, West 
Virginia, Wood Frog

\section{Introduction}

Wetland mitigation aims to replace lost wetlands through the creation or restoration of new wetlands, although it is unclear whether mitigation projects adequately replace wetland function. Functional assessment of created and restored wetlands has been the subject of many studies, typically comparing the functional attributes of created wetlands to those seen in natural reference wetlands to evaluate if successful wetlands have developed [1]. Studies tend to focus on soil characteristics, vegetative cover, hydrology, physiochemistry, plant litter decomposition rates, and wildlife species richness and diversity [2] [3] [4] [5] [6]. To date, many of the studies evaluating the success of created wetlands focus on the three primary wetland characteristics [7]: hydric soils [8] [9], hydrophytic vegetation [2] [9] [10] [11] [12], and hydrology [3] [13]. Each of these studies results in differing conclusions about the functional success of wetland mitigation. Increasingly more emphasis is being placed on how amphibians [14] [15] [16] [17] [18] and other wildlife [6] [19] are able to use these newly created habitat options. The ability of a created wetland to replace lost wildlife habitat and to support wildlife populations are important factors to include in the assessment of created wetland success.

Amphibians can comprise a large proportion of the vertebrate biomass in temperate wetlands. Anurans in particular spend some or all of their life cycle in wetlands, relying on wetlands for breeding, larval development, foraging, and hibernation [20] [21] [22]. Anurans play an important role within a wetland ecosystem by acting as primary consumers and altering algal communities, as well as by serving as a food source for higher trophic levels [23]. The ability of amphibians to use both aquatic and terrestrial habitats makes them vulnerable to a wide range of biotic and abiotic stressors [24]. Due to this substantial environmental sensitivity, amphibians are facing dramatic global declines [25] [26] [27] and are considered the most imperiled taxonomic class of vertebrates [28]. In the US, habitat loss and alteration are likely the most significant contributors to amphibian decline [29]. With the high frequency of wetland loss, which is critical habitat for amphibians, it is crucial that wetland mitigation successfully functions to replace any lost wetland habitat.

The ability of anurans to sustain a viable population in wetlands depends on their ability to hatch, grow, undergo metamorphosis, and then survive until the following spring so they can breed [30]. Tadpoles in the larval development stage are particularly sensitive to aquatic habitat quality, so water quality in breeding pools can be an important determinant of amphibian species composition, richness, and abundance beyond the larval stage [31]. The presence of amphibians alone cannot be accurately used to indicate the ability of a created wetland to function as a habitat that can support a persistent amphibian population. 
Intensive monitoring, including measures of reproductive success and juvenile recruitment, is essential for the proper assessment of the functional success of created wetlands [20] [32]. Recruitment has been proposed as a better predictor of population health than reproductive effort because created wetlands could be ecological traps where adults breed, but larvae are unable to properly develop [33].

The effects of wetland water quality characteristics on larval development are important at the population level of amphibians. Alteration of water quality in the larval habitat can lead to phenotypic variation in traits that affect metamorphosis and fitness [34]. For example, larger body size at metamorphosis may result in larger size at first reproduction, higher fecundity, and earlier time to first reproduction [35]. However, having a longer larval period puts the tadpole at risk of high levels of predation and other potential threats, such as pond drying. The ideal larval habitat conditions for an amphibian population would allow tadpoles to grow to a large body size in a short period of time. Poor conditions in the aquatic environment could cause tadpoles to metamorphose earlier and smaller than tadpoles under high quality conditions [36], although age and size at metamorphosis may not respond equally to environmental factors [37]. Stream amphibian assemblages are negatively affected by phosphate, nitrate, and total coliforms, and positively correlated with conductivity and dissolved oxygen levels [38]. It is important to investigate how parameters of water quality affect the mechanisms of tadpole growth, development, and survival so that the effects on the overall population can then be fully understood. In this study, we used mesocosms to highlight the effects of water quality on wood frog (Lithobates sylvaticus) and spring peeper (Pseudacris crucifer) larval development and to evaluate the functional success of created wetlands by comparing water quality and rates of anuran metamorphosis between created wetlands and natural reference wetlands in West Virginia, USA.

\section{Methods and Materials}

\subsection{Study Area}

Our study evaluated three created (Sugar Creek, Pleasant Creek Wildlife Management Area (WMA), Upper Deckers Creek WMA) and three natural (Meadowville, Pleasant Creek, Upper Deckers Creek) wetlands in north-central West Virginia, USA ([39]; Figure 1). Created wetlands and natural wetlands were selected in pairs, so that each pair contained one created wetland and one natural wetland (Sugar Creek-Meadowville; Pleasant Creek WMA-Pleasant Creek; Upper Deckers Creek WMA-Upper Deckers Creek). Each wetland pair was selected to have a similar location, elevation, underlying geology, and watershed (Table 1). Most of the created wetlands contained large areas of open water while all of the natural wetlands contained areas of scrub-shrub habitat. All of the wetlands had some level of disturbance adjacent to them, caused by paved roads, gravel roads, hiking trails, housing, or mowing. 
Table 1. Characteristics of three created wetlands and three natural wetlands in West Virginia, USA including whether it is a created $(\mathrm{C})$ or natural $(\mathrm{N})$ wetland, age of wetland (years), size (ha), elevation (m), dominant wetland class (all wetlands are palustrine), watershed, underlying geology, and Universal Transverse Mercator (UTM) coordinates used in an amphibian metamorphosis study, 2014-2015.

\begin{tabular}{|c|c|c|c|c|c|c|c|c|c|}
\hline Name & Type & Age & Size & Elevation & Palustrine Class ${ }^{\mathrm{a}}$ & Watershed & Geology & UTM Y & UTM X \\
\hline Sugar Creek & $\mathrm{C}$ & 20 & 6.8 & 479 & Scrub-shrub & $\begin{array}{l}\text { Tygart Valley } \\
\text { River }\end{array}$ & Shale, sandstone & $4,328,850$ & 591,470 \\
\hline $\begin{array}{l}\text { Pleasant Creek } \\
\text { WMA }\end{array}$ & $\mathrm{C}$ & 14 & 7.5 & 490 & $\begin{array}{l}\text { Emergent, unconsolidated } \\
\text { bottom }\end{array}$ & $\begin{array}{l}\text { Tygart Valley } \\
\text { River }\end{array}$ & Shale & $4,343,042$ & 579,237 \\
\hline $\begin{array}{l}\text { Upper Deckers } \\
\text { Creek WMA }\end{array}$ & $\mathrm{C}$ & 47 & 6.5 & 520 & $\begin{array}{l}\text { Aquatic bed, } \\
\text { unconsolidated bottom }\end{array}$ & $\begin{array}{l}\text { Monongahela } \\
\text { River }\end{array}$ & Shale, sandstone & $4,375,719$ & 602,837 \\
\hline Meadowville & $\mathrm{N}$ & - & 6.6 & 468 & Scrub-shrub, emergent & $\begin{array}{l}\text { Tygart Valley } \\
\text { River }\end{array}$ & Shale, sandstone & $4,330,920$ & 593,940 \\
\hline Pleasant Creek & $\mathrm{N}$ & - & 3.0 & 355 & Scrub-shrub & $\begin{array}{l}\text { Tygart Valley } \\
\text { River }\end{array}$ & Shale & $4,344,309$ & 583,743 \\
\hline $\begin{array}{l}\text { Upper Deckers } \\
\text { Creek }\end{array}$ & $\mathrm{N}$ & - & 2.6 & 512 & $\begin{array}{c}\text { Aquatic bed, scrub-shrub, } \\
\text { emergent }\end{array}$ & $\begin{array}{l}\text { Monongahela } \\
\text { River }\end{array}$ & Shale, sandstone & $4,377,282$ & 602,193 \\
\hline
\end{tabular}

${ }^{\mathrm{a} B a s e d}$ on [7].

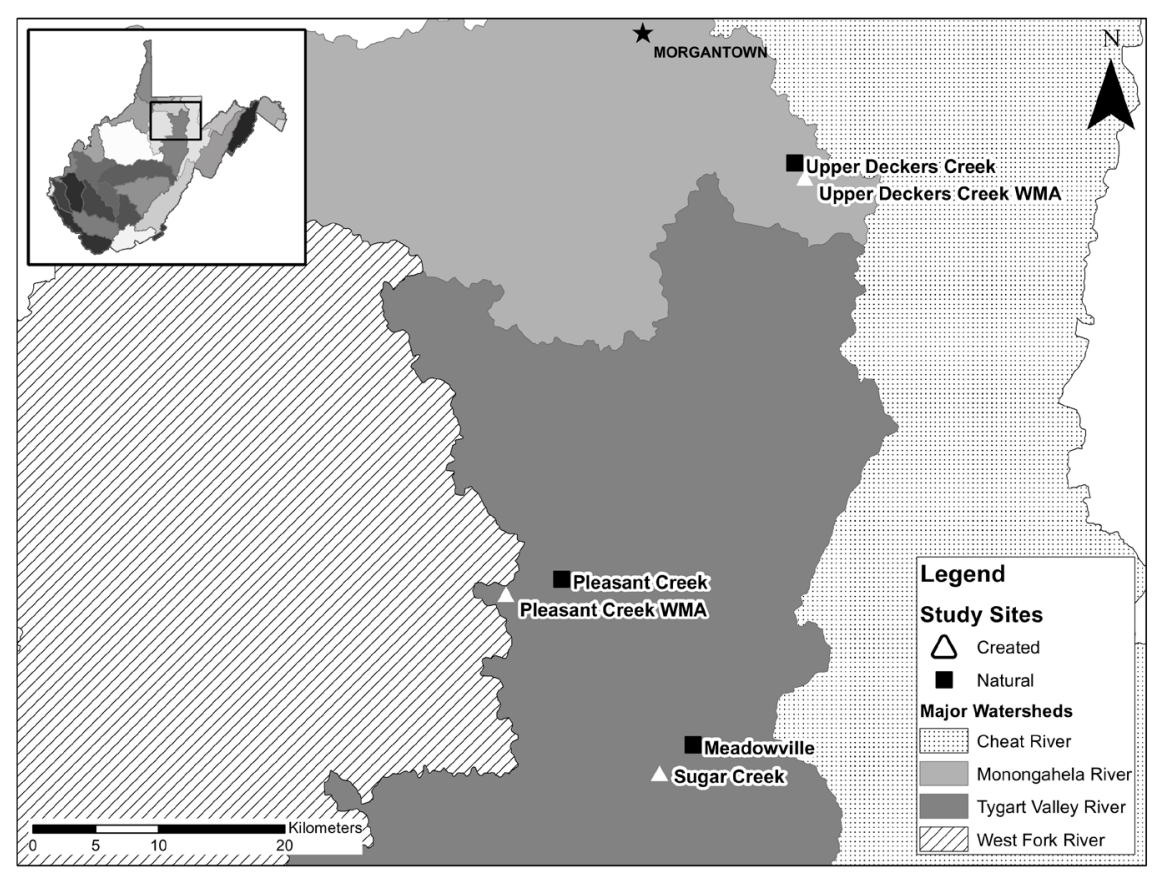

Figure 1. Six wetland sites in West Virginia, USA were included in the wetland comparison study that ran from March 2014 through July 2015. Three of these wetlands were created and three were natural wetlands.

The tadpoles in this study were housed in outdoor mesocosm aquaria $(\sim 150 \mathrm{~L}$ plastic wading pools) at the West Virginia University Organic Research Farm in Morgantown, West Virginia. The created $(\mathrm{n}=3)$ and natural $(\mathrm{n}=3)$ wetlands were represented by mesocosms in this experiment. Several weeks prior to tadpole introduction, pools were filled with $100 \mathrm{~L}$ of water from respective wetlands. We added $100 \mathrm{~g}$ of dried leaf litter comprised largely of American syca- 
more (Platanus occidentalis) [40] and $1 \mathrm{~g}$ of rabbit chow to support the establishment of periphyton. Each pool was covered with a $121 \mathrm{~cm} \times 121 \mathrm{~cm}$ sheet of fiberglass window screening secured with bungee cords and binder clips to prevent colonization of insects or other amphibians. To mimic realistic temporal changes in wetland water chemistry and to replace water lost through evaporation, $\sim 12 \mathrm{~L}$ of water from created and natural wetland sites were collected and added to respective pools each week. The pools were positioned on an open grass field so that all pools received the same amount of sunlight. Keeping all other habitat factors constant between pools (shade, water depth, size, density, leaf litter, elevation) allowed us to focus exclusively on water quality effects on metamorphosis.

\subsection{Larval Development}

Two anuran species were used in this study: wood frog and spring peeper. These species were selected because they are abundant in north-central West Virginia and collecting several hundred individuals (240 of each species in 2014, 360 of each species in 2015) was not likely to have any impact on their population. Additionally, both species have relatively early breeding times (late February through March in wood frogs; March through May in spring peepers), so tadpoles of each species were collected at similar times.

On April 10, 2014, we collected a single wood frog egg mass from one natural palustrine emergent wetland near Morgantown, West Virginia. The egg mass was transferred to a glass aquarium in the laboratory and housed in $25^{\circ} \mathrm{C}$ wetland water oxygenated with an air pump. Once the eggs hatched, the tadpoles were fed rabbit chow (Purina Rabbit Chow; Purina Animal Nutrition Center, Gray Summit, Missouri USA) ad libitum until they reached Gosner stage (GS) 25 [41] (April 30, 2014), at which point 240 randomly selected tadpoles were transferred to the experimental mesocosm pools. On May 17, 2014, early stage spring peeper tadpoles were collected from one created wetland (palustrine unconsolidated shore with mud) near Morgantown (because spring peepers lay their eggs singly, it is easier to collect them after they hatch). The tadpoles were transferred to the laboratory, housed in $25^{\circ} \mathrm{C}$ oxygenated wetland water and fed rabbit chow ad libitum for a 48-hour acclimation period, and then 240 spring peeper tadpoles were randomly selected for the same experimental pools (added May 19, 2014). Each of the six wetland study sites were represented by four mesocosm pools, with a total of 24 pools each containing 10 wood frogs and 10 spring peepers.

In the second year of the study (2015), we accounted for potential inherent differences between frogs collected from created wetlands and frogs collected from natural wetlands (differences based on which wetland type embryos developed in). On April 5, 2015, we collected one wood frog egg mass from a natural palustrine emergent wetland and on April 23, 2015, we collected recently hatched wood frog tadpoles from a created palustrine scrub-shrub wetland near Morgantown, West Virginia (by the time we were able to find wood frog eggs in 
a created wetland, they had already hatched). Both batches of wood frogs were transported to the laboratory, kept under the same conditions as in 2014, and then 180 tadpoles from each wetland source were randomly selected to be placed in the mesocosm pools (added May 1-3, 2015). On May 11, 2015, early stage spring peeper tadpoles were collected from a natural palustrine scrub-shrub wetland and on May 19, 2015, early stage spring peeper tadpoles were collected from a created palustrine emergent wetland near Morgantown, West Virginia. Tadpoles were transported to the laboratory, kept under the same conditions as in 2014, and then 180 tadpoles from each wetland source were randomly selected to be placed in the mesocosm pools (added May 11-19, 2015). Tadpoles from created and natural wetlands were housed in separate pools so that source wetland effects could be evaluated. Each of the 6 wetland study sites were represented by 6 mesocosm pools: 3 pools contained wood frogs and spring peepers that were collected from natural wetlands; 3 pools contained wood frogs and spring peepers that were collected from created wetlands. There were a total of 36 pools each containing 10 wood frogs and 10 spring peepers.

As larvae neared metamorphosis, they were checked daily for the emergence of front limbs (GS 42). At the time of front limb emergence, metamorphs were removed from pools, transported to the laboratory, weighed, and transferred to individual $500 \mathrm{~mL}$ plastic cups with $\sim 20 \mathrm{~mL}$ water and a clean paper towel to allow them to climb out of the water during tail resorption. These cups were covered with fiberglass window screen to prevent the metamorphs from escaping their cups. Metamorphs in cups were also checked daily for completion of metamorphosis and weighed once they did complete metamorphosis (full tail resorption, GS 46). In addition to measuring the mass of each subject at GS 42 and GS 46 and the snout-vent length (SVL: tip of snout to posterior end of the vent) at GS 46, we also determined the length of the larval period from the day they entered the mesocosm until they completed metamorphosis. Frogs surviving through metamorphosis were euthanized with $5 \mathrm{~g} / \mathrm{L}$ tricaine methane sulfonate (MS-222) to eliminate the risk of spreading any diseases contracted in the laboratory to wild populations.

\subsection{Water Quality}

In 2014, we measured dissolved oxygen ( $\%, \pm 2 \%$ accuracy) from three samples of each pool once a week using a YSI $^{\mathrm{TM}}$ Model 55 meter (YSI Inc., Yellow Springs, $\mathrm{OH})$ and $\mathrm{pH}( \pm 0.01$ accuracy), conductivity ( $\mu \mathrm{S}, \pm 2 \%$ full scale accuracy), and water temperature $\left({ }^{\circ} \mathrm{C}, \pm 1^{\circ} \mathrm{C}\right.$ accuracy) from three samples of each pool once a week using an ExStik ${ }^{\circledR}$ EC500 (Extech ${ }^{\circledR}$ Instruments Corporation, Nashua, NH). These meter measurements were taken throughout the day from $0900 \mathrm{~h}$ to $1600 \mathrm{~h}$. We also collected water samples weekly (the same day as the meter measurements) from each pool at $0830 \mathrm{~h}$, stored them in a cooler, and transported them to the laboratory. There, we used a Hach Multimeter (DR 3900 Benchtop Spectrophotometer; Hach ${ }^{\circledR}$ Company, Loveland, CO) to measure total nitrogen (range: 1 - $16 \mathrm{mg} / \mathrm{L} \mathrm{N}, \pm 0.1 \mathrm{mg} / \mathrm{L}$ accuracy), ammonia (range: 1 - 12 
$\mathrm{mg} / \mathrm{L} \mathrm{NH}_{3}-\mathrm{N}, \pm 0.03 \mathrm{mg} / \mathrm{L}$ accuracy), nitrate (range: $0.23-13.50 \mathrm{mg} / \mathrm{L} \mathrm{NO}_{3}-\mathrm{N}$, $\pm 0.3 \mathrm{mg} / \mathrm{L}$ accuracy), and nitrite (range: $0.015-0.600 \mathrm{mg} / \mathrm{L} \mathrm{NO}_{2}-\mathrm{N}, \pm 0.01 \mathrm{mg} / \mathrm{L}$ accuracy) of each pool sample. The mutimeter measurements were taken from one sample from each mesocosm pool each week. We collected the same water quality measurements weekly from each wetland site, where all measurements were taken and samples were collected throughout the day from $0900 \mathrm{~h}$ to 1800 $h$. The water quality measurements at the wetland sites were taken the same day that water was collected to bring back to the mesocosms. The water quality measurements in the mesocosms were taken the day after new wetland water was added. Water quality was measured May 18-June 7, 2014. Ammonia, nitrate, and nitrite were eliminated from analysis because the measurements fell below the reading range of the test kits being used.

In 2015, we performed the same water quality procedures as in 2014. However, we eliminated ammonia, nitrate, and nitrite and we added measurements of total phosphorus (range: $0.15-4.5 \mathrm{mg} / \mathrm{L} \mathrm{PO}_{4}, \pm 0.02 \mathrm{mg} / \mathrm{L}$ accuracy), and alkalinity (range: 25 - $400 \mathrm{mg} / \mathrm{L} \mathrm{CaCO}_{3}, \pm 0.09 \mathrm{mmol} / \mathrm{L}$ accuracy). Phosphorus and alkalinity were each measured once in each mesocosm pool and each wetland site per week. Water quality was measured May 10-June 20, 2015.

\subsection{Statistical Analysis}

The means of days to GS 46, mass at GS 46, and SVL at GS 46 from each mesocosm pool were used in analyses. The time to GS 46 , mass at GS 46 , and SVL at GS 46 were found to be normally distributed using Shapiro-Wilk W test. The water quality measurements of dissolved oxygen, $\mathrm{pH}$, conductivity, temperature, and total nitrogen (as well as phosphorus and alkalinity in 2015) were measured weekly as continuous variables. The water quality variables were found to be normally distributed using Shapiro-Wilk W test, except for total nitrogen which was $\log$ transformed. The means of each water quality variable from each mesocosm pool were averaged across weeks for analyses. To compare the water quality from the mesocosm pools to the water quality taken directly from the wetland sites, we used a matched pairs analysis of variance with wetland source (mesocosm, wetland) as the paired columns and wetland type (created, natural) as the grouping variable. We used the pool means and then averaged the pool means and wetland means across weeks for the paired t-test. We did the paired $\mathrm{t}$-tests separately for each year because the metamorphosis data were analyzed separately by year.

We used canonical correspondence analysis (CCA; [42]) using the software package $\mathrm{R}$ (http://cran.r-project.org/) to correlate water quality variables to metamorphosis endpoints. Canonical correspondence analysis is a multivariate direct ordination method that incorporates linear regression to summarize variation in a response related to environmental variables [43] [44]. We used CCA separately for each species and for each year. In the first CCA, we used metamorphosis endpoints as the dependent variables and wetland type as the envi- 
ronmental (independent) variable (created, natural). The second CCA used water quality variables as the dependent variables and wetland type as the environmental variables. The third CCA used metamorphosis endpoints as the dependent variables and water quality as the environmental variables. We used eigenvalues ( $\lambda$; relative ability of an axis to separate response distribution; [45]) and percentage of variation explained in the dependent variables to assess the relative importance of environmental variables in structuring the responses, and we used correlation coefficients to assess the relative importance of water quality variables on metamorphosis. We performed an analysis of variance (ANOVA) with 999 permutations to test the null hypothesis that there was no relation between dependent variables and environmental variables for each CCA. We determined the significance of correlations between matrices only by axis one p-values, because axis one accounted for the most variation in all analyses [45].

We conducted additional univariate analyses on the data to investigate relations between dependent variables and environmental variables when they appeared to have a strong response in the CCA. ANOVAs were performed when wetland type was the environmental variable, and forward stepwise regression was used when water quality was used as the environmental variables. Analyses of covariance (ANCOVA) were done with Program PROC GLM (SAS ${ }^{\circledast}$ v9.1.3) on significant water quality factors from regression to identify interactions between water quality variables and wetland type on metamorphosis. In the ANCOVAs, each water quality variable was the covariate and wetland type was the grouping variable. Results for all tests were considered significant when $\mathrm{p}<0.1$.

\section{Results}

\subsection{Results 2014}

When we compared water quality between the mesocosm pool and the source wetlands, we found that $\mathrm{pH}$, temperature, and nitrogen were similar between the pools and the wetlands (Table 2$)$. Dissolved oxygen $(p=0.002)$ and conductivity $(p=0.022)$ were higher in the wetlands than in the pools.

The results of the first CCA relating variation in metamorphosis data to wetland type indicated that spring peepers were not significantly affected by wetland type $\left(\mathrm{F}_{1,22}=0.885, \mathrm{p}=0.375, \lambda=0.00005,3.87 \%\right.$ variance explained $)$. However, wood frog metamorphosis was influenced by wetland type $\left(\mathrm{F}_{1,22}=13.445, \mathrm{p}=\right.$ $0.001, \lambda=0.0002,37.93 \%$ variance explained). Wood frog tadpoles raised in natural wetland water reached metamorphosis in less time $(\bar{x}=39.092$ days, SE $=0.203)$ than those in created wetland water $(\bar{x}=40.486$ days, $\mathrm{SE}=0.378)\left(\mathrm{F}_{1,22}\right.$ $=10.55, \mathrm{p}=0.004$; Table 3). Additionally, wood frogs in natural wetland water reached an SVL $(\bar{X}=15.230 \mathrm{~mm}, \mathrm{SE}=0.123)$ that was longer than those in created wetland water $(\bar{x}=14.796 \mathrm{~mm}, \mathrm{SE}=0.170)\left(\mathrm{F}_{1,22}=4.273, \mathrm{p}=0.050\right)$. A similar relation occurred in body mass, where wood frogs in natural wetlands reached a body mass $(\bar{x}=0.662 \mathrm{~g}, \mathrm{SE}=0.020)$ that was heavier than those in created wetlands $(\bar{x}=0.598 \mathrm{~g}, \mathrm{SE}=0.024)\left(\mathrm{F}_{1,22}=4.227, \mathrm{p}=0.052\right)$. 
Table 2. Average values of each water quality variable in created and natural mesocosm pools and created and natural source wetlands, as well as the results from the matched pairs analysis of variance with wetland source as the paired columns ( $t$ test; $\mathrm{df}=5$ ) and wetland type as the grouping variable ( $F$ ratio; $d f=1,5$ ), in West Virginia, USA 2014-2015.

\begin{tabular}{|c|c|c|c|c|c|c|c|c|c|c|}
\hline \multirow{2}{*}{ Year } & \multirow{2}{*}{ Water Factor } & \multirow{2}{*}{$\begin{array}{c}\text { Wetland } \\
\text { Type }\end{array}$} & \multicolumn{2}{|c|}{ Pool } & \multicolumn{2}{|c|}{ Wetland } & \multirow{2}{*}{$\mathrm{t}$ test } & \multirow{2}{*}{$\mathrm{p}$-value } & \multirow{2}{*}{$F$ ratio } & \multirow{2}{*}{$\mathrm{p}$-value } \\
\hline & & & $\bar{x}$ & SE & $\bar{x}$ & SE & & & & \\
\hline \multirow{2}{*}{2014} & \multirow{2}{*}{$\begin{array}{c}\text { Dissolved } \\
\text { Oxygen (\%) }\end{array}$} & Created & 39.5 & 2.099 & 57.6 & 11.830 & \multirow{2}{*}{5.633} & \multirow{2}{*}{$0.002^{\star}$} & \multirow{2}{*}{0.463} & \multirow{2}{*}{0.534} \\
\hline & & Natural & 35.6 & 1.892 & 49.6 & 8.316 & & & & \\
\hline \multirow[b]{2}{*}{2014} & \multirow[b]{2}{*}{$\mathrm{pH}$} & Created & 7.55 & 0.045 & 7.58 & 0.195 & \multirow[b]{2}{*}{-0.012} & \multirow[b]{2}{*}{0.991} & \multirow[b]{2}{*}{0.024} & \multirow[b]{2}{*}{0.885} \\
\hline & & Natural & 7.26 & 0.039 & 7.24 & 0.188 & & & & \\
\hline \multirow{2}{*}{2014} & \multirow{2}{*}{$\begin{array}{l}\text { Conductivity } \\
\qquad(\mu \mathrm{S})\end{array}$} & Created & 192.8 & 18.841 & 239.1 & 27.508 & \multirow{2}{*}{3.287} & \multirow{2}{*}{$0.022^{\star}$} & \multirow{2}{*}{0.896} & \multirow{2}{*}{0.397} \\
\hline & & Natural & 176.0 & 15.520 & 195.2 & 17.940 & & & & \\
\hline \multirow{2}{*}{2014} & \multirow{2}{*}{$\begin{array}{c}\text { Temperature } \\
\left({ }^{\circ} \mathrm{C}\right)\end{array}$} & Created & 21.9 & 0.302 & 20.5 & 1.586 & \multirow{2}{*}{-0.718} & \multirow{2}{*}{0.748} & & \\
\hline & & Natural & 21.4 & 0.206 & 20.6 & 1.547 & & & & \\
\hline 2014 & Nitrogen & Created & 1.60 & 0.160 & 1.42 & 0.483 & 360 & ס? 0 & & 0404 \\
\hline 2011 & $(\mathrm{mg} / \mathrm{L} \mathrm{N})$ & Natural & 1.58 & 0.123 & 0.91 & 0.085 & 1.000 & 0.225 & 0.000 & . \\
\hline 2015 & Dissolved & Created & 36.6 & 3.679 & 51.4 & 6.230 & 370 & ח? & 1130 & 0348 \\
\hline 2010 & Oxygen (\%) & Natural & 36.3 & 2.236 & 38.4 & 3.701 & 1.08 & 0.203 & 10.00 & 80 \\
\hline 2015 & $\mathrm{nH}$ & Created & 7.75 & 0.097 & 7.39 & 0.096 & & $0008^{*}$ & 0688 & 0453 \\
\hline & & Natural & 7.57 & 0.057 & 7.01 & 0.102 & & & & \\
\hline & Conductivity & Created & 165.9 & 21.667 & 262.3 & 36.427 & & & & \\
\hline 2010 & $(\mu \mathrm{S})$ & Natural & 126.7 & 4.338 & 269.6 & 32.090 & 2.020 & 0.000 & 0.10 & (.) \\
\hline & Temperature & Created & 23.7 & 0.113 & 21.1 & 1.068 & & & & \\
\hline 20.0 & $\left({ }^{\circ} \mathrm{C}\right)$ & Natural & 23.8 & 0.101 & 22.5 & 0.968 & & & & - \\
\hline & Nitrogen & Created & 1.58 & 0.126 & 1.64 & 0.257 & & & & \\
\hline 2015 & $(\mathrm{mg} / \mathrm{L} \mathrm{N})$ & Natural & 1.79 & 0.128 & 1.31 & 0.174 & & 0.500 & 0.202 & 0.007 \\
\hline & Phosphorus & Created & 0.302 & 0.030 & 0.366 & 0.068 & & & & \\
\hline 2010 & $\left(\mathrm{mg} / \mathrm{L} \mathrm{PO}_{4}\right)$ & Natural & 0.454 & 0.064 & 0.291 & 0.050 & 01 & 0.489 & 0.139 & 0.453 \\
\hline & Alkalinity & Created & 61.3 & 2.802 & 90.2 & 9.216 & & & & \\
\hline 2010 & $\left(\mathrm{mg} / \mathrm{L} \mathrm{CaCO}_{3}\right)$ & Natural & 55.1 & 2.349 & 70.4 & 7.441 & & & & \\
\hline
\end{tabular}

*Significant $(\alpha=0.1)$.

Table 3. Average values of metamorphosis endpoints, specifically days to Gosner stage (GS) 46 [41] and mass and snout-vent length (SVL) at GS 46, for spring peepers and wood frogs in created and natural wetlands of West Virginia, USA as well as the analysis of variance results comparing created and natural means, in 2014 and 2015.

\begin{tabular}{|c|c|c|c|c|c|c|c|c|c|c|c|}
\hline \multirow{2}{*}{ Year } & \multirow{2}{*}{ Species } & \multirow{2}{*}{$\begin{array}{c}\text { Wetland } \\
\text { type }\end{array}$} & \multicolumn{2}{|c|}{ Days to GS 46} & \multicolumn{4}{|c|}{$\mathrm{p}$-value Mass at GS $46 \mathrm{p}$-value } & \multicolumn{2}{|c|}{ SVL at GS 46} & \multirow[t]{2}{*}{ p-value } \\
\hline & & & $\bar{x}$ & SE & & $\bar{x}$ & SE & & $\bar{x}$ & SE & \\
\hline \multirow{2}{*}{2014} & Spring & Created & 24.981 & 0.462 & \multirow{2}{*}{$0.255^{\mathrm{a}}$} & 0.173 & 0.008 & \multirow{2}{*}{$0.703^{\mathrm{b}}$} & 9.880 & 0.160 & \multirow{2}{*}{$0.968^{c}$} \\
\hline & Peeper & Natural & 24.205 & 0.478 & & 0.177 & 0.008 & & 9.872 & 0.133 & \\
\hline
\end{tabular}




\section{Continued}

\begin{tabular}{|c|c|c|c|c|c|c|c|c|c|c|c|}
\hline \multirow{2}{*}{2015} & Spring & Created & 28.796 & 0.426 & \multirow{2}{*}{$0.993^{\mathrm{d}}$} & 0.189 & 0.010 & \multirow{2}{*}{$0.784^{\mathrm{e}}$} & 10.444 & 0.254 & \multirow{2}{*}{$0.624^{\mathrm{f}}$} \\
\hline & Peeper & Natural & 28.803 & 0.631 & & 0.192 & 0.006 & & 10.569 & 0.120 & \\
\hline \multirow{2}{*}{2014} & & Created & 40.486 & 0.378 & \multirow{2}{*}{$0.004^{g *}$} & 0.598 & 0.024 & \multirow{2}{*}{$0.052^{\mathrm{h} x}$} & 14.796 & 0.170 & \multirow{2}{*}{$0.050^{i \times}$} \\
\hline & mover & Natural & 39.092 & 0.203 & & 0.662 & 0.020 & & 15.230 & 0.123 & \\
\hline \multirow{2}{*}{2015} & Wood Erog & Created & 33.040 & 0.655 & \multirow{2}{*}{$0.379^{j}$} & 0.633 & 0.031 & \multirow{2}{*}{$0.483^{\mathrm{k}}$} & 15.469 & 0.240 & \multirow{2}{*}{$0.147^{1}$} \\
\hline & & Natural & 34.002 & 0.837 & & 0.606 & 0.023 & & 14.960 & 0.240 & \\
\hline
\end{tabular}

${ }^{*}$ Significant $(\alpha=0.05) .{ }^{\mathrm{a}} \mathrm{F}_{1,22}=1.365 ;{ }^{\mathrm{b}} \mathrm{F}_{1,22}=0.149 ;{ }^{\mathrm{c}} \mathrm{F}_{1,22}=0.002 ;{ }^{\mathrm{d}} \mathrm{F}_{1,28}=0 ;{ }^{\mathrm{e}} \mathrm{F}_{1,28}=0.076 ;{ }^{\mathrm{f}} \mathrm{F}_{1,28}=0.245 ;{ }^{\mathrm{g}} \mathrm{F}_{1,22}=$ $10.55 ;{ }^{\mathrm{h}} \mathrm{F}_{1,22}=4.227 ;{ }^{\mathrm{i}} \mathrm{F}_{1,22}=4.273 ;{ }^{j} \mathrm{~F}_{1,25}=0.803 ;{ }^{\mathrm{k}} \mathrm{F}_{1,25}=0.507 ;{ }^{1} \mathrm{~F}_{1,25}=2.242$.

The results of the second CCA relating variation in water quality data to wetland type indicated that wetland type did not influence water quality $\left(\mathrm{F}_{1,22}=\right.$ $0.106, p=0.844, \lambda=0.0001,0.48 \%$ variance explained). The results of the third CCA relating variation in metamorphosis data to water quality indicated that water quality did not influence metamorphosis in spring peepers or in wood frogs (Table 4).

\subsection{Results 2015}

The initial mass of the spring peeper tadpoles collected from created wetlands $(\bar{X}=0.081, \mathrm{SE}=0.006)$ was significantly higher than the initial mass of those collected from natural wetlands $(\bar{X}=0.051, \mathrm{SE}=0.006)\left(\mathrm{F}_{1,47}=12.63, \mathrm{p}=\right.$ $0.001)$. This same significant trend was observed between wood frogs collected from created wetlands $(\bar{x}=0.173, \mathrm{SE}=0.012)$ and wood frogs collected from natural wetlands $(\bar{x}=0.128, \mathrm{SE}=0.009)\left(\mathrm{F}_{1,43}=8.89, \mathrm{p}=0.005\right)$. These differences in initial mass were likely due to the collection of individuals at different developmental stages rather than other effects from embryos developing in different wetland types. Because both species contained an equal number of individuals with a smaller mass and individuals with a larger mass, we performed all analyses combining both frog sources and evaluating the species as a whole. Results from analyses including effects of frog source (wetland type where frogs were collected from) are found in [39].

When we compared water quality between the mesocosm pool and the source wetlands, we found that all water quality variables were similar between the pools and the wetlands except for $\mathrm{pH}$, which was higher in the pools than in the wetlands ( $\mathrm{p}=0.008)$, and conductivity, which was higher in the wetlands than in the pools $(\mathrm{p}=0.053)$ (Table 2$)$.

The results of the first CCA relating variation in metamorphosis data to wetland type indicate that spring peepers $\left(\mathrm{F}_{1,28}=0.076, \mathrm{p}=0.819, \lambda=0.000007\right.$, $0.27 \%$ variance explained) and wood frogs $\left(\mathrm{F}_{1,25}=2.086, \mathrm{p}=0.16, \lambda=0.002\right.$, $7.7 \%$ variance explained) were not significantly affected by wetland type (Table 3 ). The results of the second CCA relating variation in water quality data to wetland type indicate that wetland type significantly influenced water quality $\left(\mathrm{F}_{1,30}=\right.$ $2.991, \mathrm{p}=0.07, \lambda=0.0038,9.07 \%$ variance explained). Conductivity in natural 
Table 4. Summary of results from canonical correspondence analyses with water quality from West Virginia, USA wetlands as the environmental variable and metamorphosis data for spring peepers and wood frogs as the dependent variable, 2014-2015. Correlation coefficients are reported for all environmental variables.

\begin{tabular}{|c|c|c|}
\hline Variable & Axis 1 & Axis 2 \\
\hline \multicolumn{3}{|c|}{ Metamorphosis-Water Quality in Spring Peepers 2014} \\
\hline Eigenvalue $(\lambda)$ & 0.0002 & 0.00002 \\
\hline$\%$ variance explained & 16.21 & 1.13 \\
\hline p-value & 0.638 & \\
\hline DO & -0.2880 & 0.7380 \\
\hline $\mathrm{pH}$ & 0.1758 & 0.5699 \\
\hline Conductivity & 0.2945 & -0.2118 \\
\hline Temperature & 0.4257 & 0.6679 \\
\hline Nitrogen & 0.5095 & 0.1836 \\
\hline \multicolumn{3}{|c|}{ Metamorphosis—Water Quality in Spring Peepers 2015} \\
\hline Eigenvalue $(\lambda)$ & 0.0010 & 0.00002 \\
\hline$\%$ variance explained & 42.86 & 0.65 \\
\hline p-value & 0.107 & \\
\hline DO & -0.1927 & 0.7597 \\
\hline $\mathrm{pH}$ & -0.1669 & 0.5406 \\
\hline Conductivity & -0.4335 & 0.0075 \\
\hline Temperature & 0.2089 & -0.4201 \\
\hline Nitrogen & 0.0080 & -0.5195 \\
\hline Phosphorus & -0.2875 & -0.5692 \\
\hline Alkalinity & 0.1033 & -0.2088 \\
\hline \multicolumn{3}{|c|}{ Metamorphosis_-Water Quality in Wood Frogs 2014} \\
\hline Eigenvalue $(\lambda)$ & 0.0001 & 0.000001 \\
\hline$\%$ variance explained & 21.51 & 0.21 \\
\hline p-value & 0.399 & \\
\hline DO & 0.0972 & 0.4745 \\
\hline $\mathrm{pH}$ & 0.6447 & 0.3232 \\
\hline Conductivity & 0.3785 & 0.7592 \\
\hline Temperature & 0.1036 & -0.1978 \\
\hline Nitrogen & -0.1414 & 0.2983 \\
\hline \multicolumn{3}{|c|}{ Metamorphosis_-Water Quality in Wood Frogs 2015} \\
\hline Eigenvalue $(\lambda)$ & 0.0018 & 0.00004 \\
\hline$\%$ variance explained & 64.30 & 1.58 \\
\hline $\mathrm{p}$ value & $0.004^{*}$ & \\
\hline $\mathrm{DO}$ & 0.4715 & 0.6856 \\
\hline $\mathrm{pH}$ & 0.2929 & 0.5543 \\
\hline Conductivity & 0.0607 & 0.2909 \\
\hline Temperature & 0.0116 & -0.1441 \\
\hline Nitrogen & 0.5007 & -0.7826 \\
\hline Phosphorus & 0.6612 & -0.5293 \\
\hline Alkalinity & 0.1755 & 0.1909 \\
\hline
\end{tabular}

*Significant $(\alpha=0.05)$. 
wetland water $(\bar{x}=126.6 \mu \mathrm{S}, \mathrm{SE}=4.600)$ was lower than the conductivity in created wetland water $(\bar{x}=165.9 \mu \mathrm{S}, \mathrm{SE}=21.667)\left(\mathrm{F}_{1,30}=3.989, \mathrm{p}=0.055\right)$.

The results of the third CCA relating variation in metamorphosis data to water quality indicate that water quality did not influence metamorphosis in spring peepers, but wood frog metamorphosis was influenced by water quality $(\mathrm{p}=0.004)$ (Table 4). Specifically, the results from stepwise regression indicated that days to metamorphosis for wood frogs were positively influenced by $\mathrm{pH}\left(\mathrm{F}_{1,24}=4.68, \mathrm{p}=\right.$ 0.041) (Figure 2). Mass at metamorphosis was negatively influenced by dissolved oxygen $\left(\mathrm{F}_{1,24}=19.49, \mathrm{p}=0.0002\right)$ (Figure 3$)$. SVL at metamorphosis was negatively

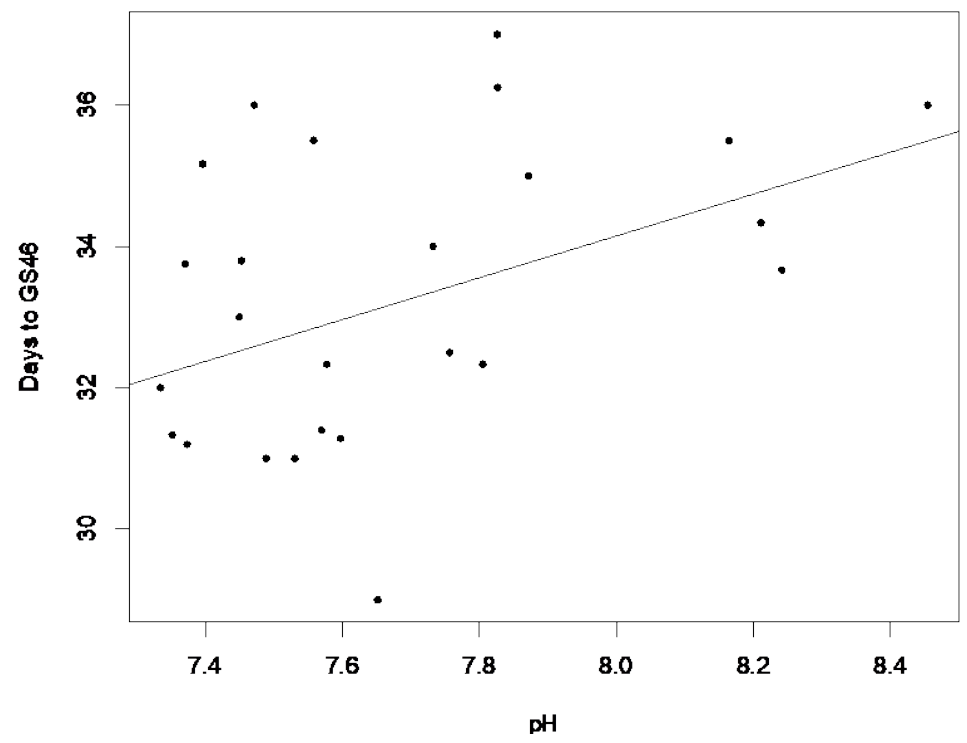

Figure 2. Effect of $\mathrm{pH}$ in West Virginia, USA wetlands on days to metamorphosis in wood frogs in $2015(\mathrm{p}=0.041)$.

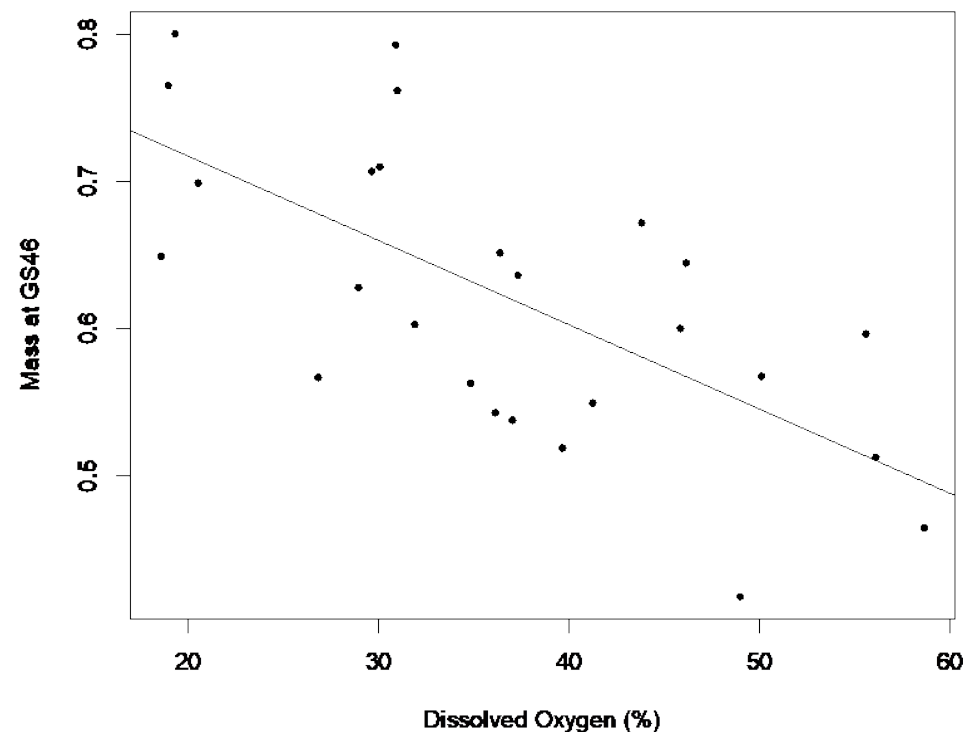

Figure 3. Effect of dissolved oxygen in West Virginia, USA wetlands on mass at metamorphosis in wood frogs in 2015 ( $\mathrm{p}=0.0002)$. Dissolved oxygen was measured in each pool once a week using a YSI ${ }^{\mathrm{TM}}$ Model 55 meter (YSI Inc., Yellow Springs, OH). 
influenced by both dissolved oxygen $\left(\mathrm{F}_{2,23}=11.57, \mathrm{p}=0.002\right)$ and phosphorus $\left(\mathrm{F}_{2,23}=6.85, \mathrm{p}=0.015\right)$ (Figure 4). ANCOVA (SVL = phosphorus + wetland type + interaction between phosphorus and wetland type) resulted in a significant interaction between phosphorus and wetland type on wood frog SVL at metamorphosis $\left(\mathrm{F}_{1,23}=5.38, \mathrm{p}=0.030\right)$ (Figure 5). In created wetlands, phosphorus did not have a significant effect on SVL $\left(t_{23}=1.57, p=0.130\right)$, but phosphorus did have a significantly negative effect on SVL in natural wetlands $\left(t_{23}=-2.29, p=0.031\right)$.

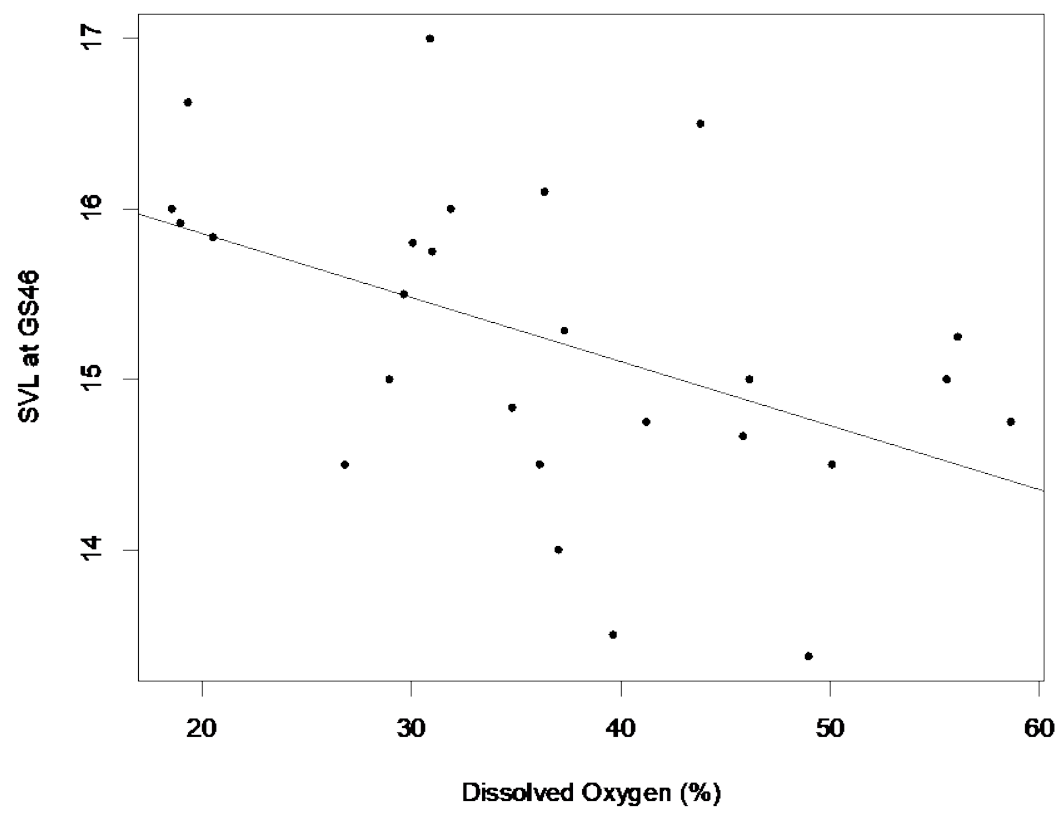

(a)

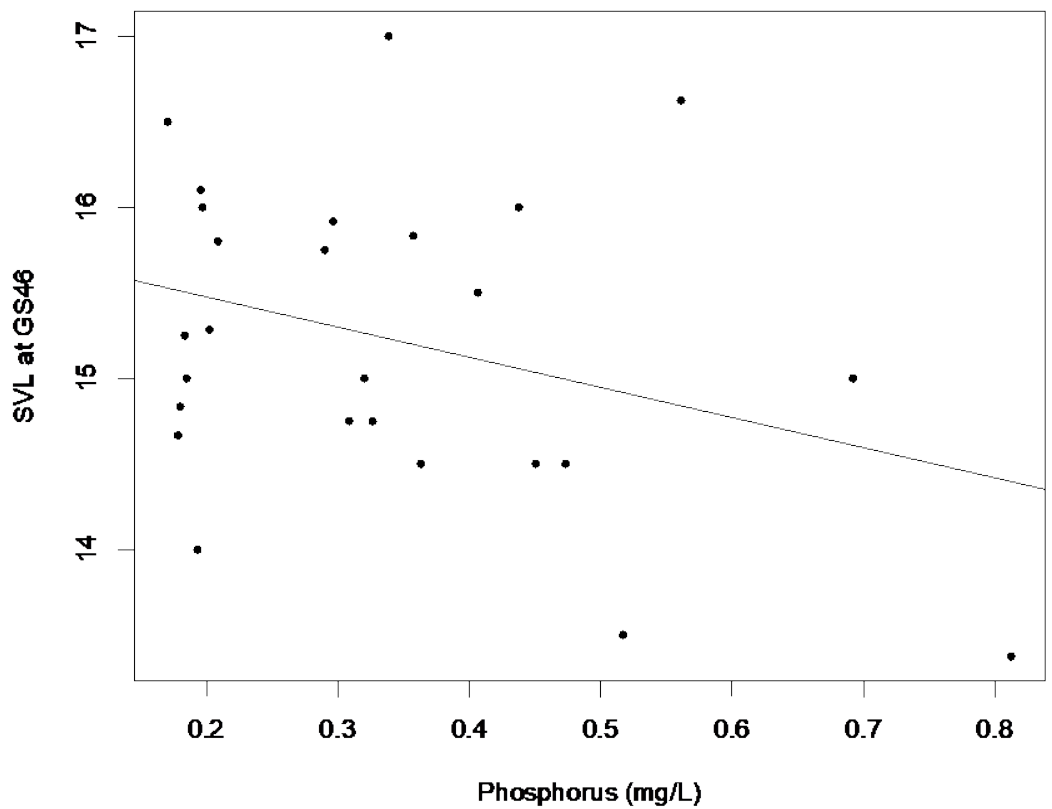

(b)

Figure 4. Effect of (a) dissolved oxygen $(\mathrm{p}=0.002)$ and $(\mathrm{b})$ phosphorus $(\mathrm{p}=0.015)$ in West Virginia, USA wetlands on snout-vent length (SVL) at metamorphosis in wood frogs in 2015. 


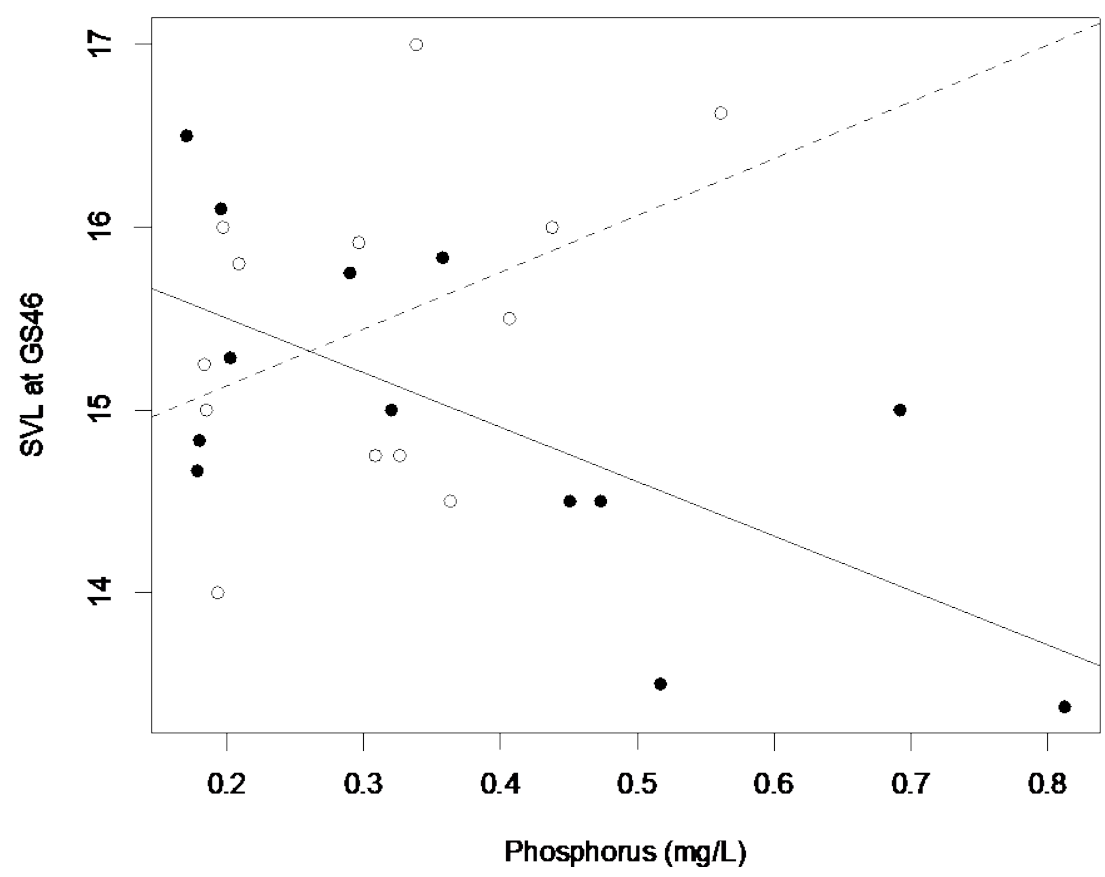

Figure 5. Effects of phosphorus on snout-vent length (SVL) of wood frogs in 2015 between created wetlands $(\mathrm{p}=0.130)$ and natural wetlands $(\mathrm{p}=0.031)$ in West Virginia, USA. Filled circles and the solid line represent natural wetlands, open circles and the dashed line represent created wetlands.

\section{Discussion}

\subsection{Rates of Metamorphosis}

Rates of spring peeper metamorphosis were similar between created and natural wetlands in both years of the study. Wood frog metamorphosis was similar between created and natural wetlands in 2015, but in 2014 wood frogs tended to reach metamorphosis more quickly and at a larger body size in natural wetlands. In 2015, we studied wood frogs from two wetlands: one egg mass from a natural wetland and recently hatched tadpoles from a created wetland. The high variance in the 2015 wood frogs could explain why we did not see effects of wetland type on their development. In 2014, we studied wood frogs from a single egg mass, where variation was more limited and effects of wetland type were more noticeable.

Few other studies that assess the functional status of created wetlands include a measure of amphibian metamorphic rates. Significantly smaller mean SVL at metamorphosis for spring peepers and ornate chorus frogs (Pseudacris ornata) have been observed at created ponds than at a reference pond, but no significant difference occurred for the other six anuran species in their study [46]. Although our study did not find an effect of wetland type on spring peeper metamorphosis, together our study and [46] suggest that frogs that metamorphose in created wetlands may have slightly reduced fitness compared to those in natural wetlands. Our study suggests that created wetlands may be providing partial mitigation in terms of water quality for amphibian development. 


\subsection{Effects of Water Quality}

The 2014 wood frogs reached a larger body size in less time in the natural wetlands than in the created wetlands, but the water variables measured in this study were not able to explain this difference in metamorphosis between wetland types. The 2015 wood frogs had similar rates of metamorphosis in the created and natural wetlands, but overall their metamorphosis was affected by the water variables, specifically $\mathrm{pH}$, dissolved oxygen, and phosphorus.

Dissolved oxygen had a negative effect on the size of wood frogs at metamorphosis in 2015, where both mass and SVL decreased with increasing levels of dissolved oxygen. The opposite trend is often seen in other studies, where higher oxygen is typically preferred by larval amphibians [47] [48] [49] [50]. Larger body mass of western chorus frogs (Pseudacris triseriata) was observed at lower levels of dissolved oxygen in year 1, but the reverse was true in the second year of study [51]. Research suggests that $20 \%$ saturation of dissolved oxygen is considered low enough for negative effects to occur on tadpoles [52] [53]. The dissolved oxygen measured in our study in 2015 ranged from $18.6 \%-58.6 \%$, with a mean of 36.3 ( \pm 2.229$)$. It is difficult to explain why the lowest values of dissolved oxygen in our study, which were as low as the "harmfully" low values seen in other studies, corresponded with the highest body sizes in wood frogs. Northern leopard frogs (Lithobates pipiens) (same genus as wood frogs) have been found in $<50 \%$ oxygen-saturated waters and this tolerance of lower oxygen environments was explained by the early development of lungs in these species [54]. In our study, low levels of dissolved oxygen and $\mathrm{pH}$ were related to a larger body size and faster development of 2015 wood frogs, respectively. This may be explained by high microbial respiration associated with decaying leaf litter [55]. Decaying plant biomass reduces oxygen and $\mathrm{pH}$ in the water, but larval wood frogs may benefit from the food source provided by decaying plant matter.

Total phosphorous had an overall negative effect on SVL of 2015 wood frogs at metamorphosis, and this trend specifically occurred in natural wetlands. Depending on the concentration, phosphorus can act as a limiting nutrient or a harmful pollutant. Higher phosphorus levels were found in constructed agricultural ponds that allowed grazing of livestock than in natural ponds [56]. They also found that African clawed frog (Xenopus laevis) survival was negatively correlated with phosphorus. We did not find differences in phosphorus concentrations between created and natural wetlands, and none of our study wetlands were grazed agricultural ponds, but we did find a difference in phosphorus effects between created and natural wetlands, where the negative effect of phosphorus on wood frogs was significantly apparent in natural wetlands. The phosphorus concentrations in our study in 2015 were relatively low, with $82 \%$ of measures falling under $0.5 \mathrm{mg} / \mathrm{L}$. This suggests that wood frogs are particularly sensitive to phosphorus in their larval environments.

\subsection{Environmental Applications}

This study focused on the effects of water quality on metamorphosis and aimed 
to identify differences in water quality between created and natural wetlands. However, there tend to be large amounts of natural variability in wetland water quality. Within-wetland differences in wetland water quality may be as large or larger than differences between wetlands [57]. A suite of water quality parameters of up to two orders of magnitude have been quantified in a series of forested wetland ponds [58]. There are many factors that can influence the water quality of a wetland, regardless of whether it is a created or a natural wetland. Landscape influences such as surrounding land use [59], the size and slope of watersheds that feed wetlands [60], and buffer zone quality [61] can affect water quality in a wetland. Water quality can also be affected by internal biological processes driven by aquatic plant photosynthesis and microbial respiration. Variation in water quality could be due to a wide range of landscape, internal, or temporal factors beyond whether a wetland is natural or manmade.

Some studies evaluate the effects of "extreme" water quality factors on larval amphibians, concluding that in conditions with water quality falling on extreme ends of a gradient, larval development may be negatively affected [62] [63] [64]. Although variation in water chemistry in our mesocosm pools was high, none of the variables reached extremely high or low values. The water chemistry observed in this study was similar to values seen in other studies of typical wetlands [58] [65]. The variation seen in water quality in our study was not sufficient to influence most metamorphosis endpoints. It is likely that the resident anurans of north-central West Virginia are tolerant of the natural range of water chemistry variation [33] [58].

Spring peepers in particular were not affected by wetland type or by the environmental variables measured in this study. Others have found that spring peepers had a high abundance in both constructed and natural wetlands [29]. Spring peepers had high reproductive success in created wetlands due to their tendency to breed in both permanent and temporary ponds [46]. However, wood frogs may be more sensitive to changes in habitat quality. In one study, wood frogs were found exclusively in natural wetlands; no wood frogs were found in the 14 created wetlands in their study [29]. Others have found breeding wood frogs in created wetlands, but reproductive success was often low [32]. Many studies agree that the exclusion of wood frogs from created wetlands is due to the large size and long hydroperiod of many created wetlands which support populations of predatory amphibian species, such as green frogs (Lithobates clamitans) and bullfrogs (Lithobates catesbeianus) [29] [32] [33]. Spring peepers can breed in and larvae can develop in temporary and permanent ponds that are natural or constructed, so they are likely to be tolerant of a range of environmental conditions. Wood frogs typically breed in forested vernal pools, which is a less variable habitat preference than that of the spring peepers, suggesting that wood frogs may be more sensitive to environmental variability.

This mesocosm design allowed us to focus on the effects of water quality. Abiotic factors, such as water chemistry, are known to affect growth and develop- 
mental rates of larval amphibians [51], although the strength and direction of the effects are highly variable and vary between sites and species. Focusing on water quality allowed us to address specific questions about the performance of created wetlands to support aquatic wildlife and to assess the phenotypic plasticity of larval amphibians in response to variation in water quality. However, the applications of our results to real wetland ecosystems are limited. The obvious next step would be to continue seeking answers to these research questions in a field-based study. While it is true that water chemistry affects rates of larval development, there are many other habitat variables that have proven to be important influences on amphibians, such as hydrology [29] [33] [43] [46], canopy cover [29] [66] [67], quality of surrounding habitat [68], and aquatic vegetative communities [47]. Water quality is driven by all of these habitat variables and data on water quality in West Virginia wetlands (and other regions) is limited. If significant differences are found in water quality between a created and a natural wetland, it may be difficult to develop management recommendations for future wetland creation without knowing which habitat features are attributing to the differing water quality. Including habitat variables along with water chemistry measures will provide the clearest explanation of how created wetlands are supporting larval amphibian development compared to natural wetlands.

\section{Acknowledgements}

We thank G.F. Strain for help selecting field sites. We thank R. Miller, R.E. Arbogast, and V.C. Grant for field and lab assistance. We thank D.J. Brown, and E.R. Merriam for their statistical advice and P. Bohall Wood for reviewing this manuscript. Funding was provided by the West Virginia University (WVU) School of Natural Resources through the McIntire-Stennis program (WVA00117; WVA00096; WVA00812) and the WVU Environmental Research Center. J.T. Anderson was supported by the National Science Foundation under Cooperative Agreement No. OIA-1458952 during manuscript preparation. We received approval to conduct this study from the WVU Institutional Animal Care and Use Committee (\#13-0905) and a scientific collecting permit was obtained from the West Virginia Division of Natural Resources (\#2014.109) to collect amphibians.

\section{Conflicts of Interest}

The authors declare no conflicts of interest regarding the publication of this paper.

\section{References}

[1] Lewis, K.A., Rota, C.T. and Anderson, J.T. (2020) A Comparison of Wetland Characteristics between Agricultural Conservation Easement Program and Public Lands Wetlands in West Virginia. Ecology and Evolution, 10, 3017-3031. https://doi.org/10.1002/ece3.6118

[2] Balcombe, C.K., Anderson, J.T., Fortney, R.H., Rentch, J.S., Grafton, W.N. and Kordek, W.S. (2005) A Comparison of Plant Communities in Mitigation and Ref- 
erence Wetlands in the Mid-Appalachians. Wetlands, 25, 130-142. https://doi.org/10.1672/0277-5212(2005)025[0130:ACOPCI]2.0.CO;2

[3] Cole, C.A. and Brooks, R.P. (2000) A Comparison of the Hydrologic Characteristics of Natural and Created Mainstem Floodplain Wetlands in Pennsylvania. Ecological Engineering, 14, 221-231. https://doi.org/10.1016/S0925-8574(99)00004-X

[4] Gingerich, R.T. and Anderson, J.T. (2011) Litter Decomposition in Created and Reference Wetlands in West Virginia, USA. Wetlands Ecology and Management, 19, 449-458. https://doi.org/10.1007/s11273-011-9228-0

[5] Gingerich, R.T., Merovich, G. and Anderson, J.T. (2014) Influence of Environmental Parameters on Litter Decomposition in Wetlands in West Virginia, USA. Journal of Freshwater Ecology, 29, 535-549. https://doi.org/10.1080/02705060.2014.926463

[6] Lewis, K.E., Rota, C.T., Lituma, C.M. and Anderson, J.T. (2019) Influence of the Agricultural Conservation Easement Program Wetland Practices on Winter Occupancy of Passerellidae Sparrows and Avian Species Richness. PLoS ONE, 14, e0210878. https://doi.org/10.1371/journal.pone.0210878

[7] Cowardin, L.M., Carter, V., Golet, F.C. and LaRoe, E.T. (1979) Classification of Wetlands and Deepwater Habitats of the United States. U.S. Fish and Wildlife Service, Report No. FWS/OBS/-79/31, Washington DC.

[8] Bruland, G.L. and Richardson, C.J. (2006) Comparison of Soil Organic Matter in Created, Restored, and Paired Natural Wetlands in North Carolina. Wetlands Ecology and Management, 14, 245-251. https://doi.org/10.1007/s11273-005-1116-Z

[9] Campbell, D.A., Costa, C.A. and Brooks, R.P. (2002) A Comparison of Created and Natural Wetlands in Pennsylvania, USA. Wetlands Ecology and Management, 10, 41-49. https://doi.org/10.1023/A:1014335618914

[10] Delphey, P.J. and Dinsmore, J.J. (1993) Breeding Bird Communities of Recently Restored and Natural Prairie Potholes. Wetlands, 13, 200-206. https://doi.org/10.1007/BF03160881

[11] Hartzell, D., Bidwell, J.R. and Davis, C.A. (2007) A Comparison of Natural and Created Depressional Wetlands in Central Oklahoma Using Metrics from Indices of Biological Integrity. Wetlands, 27, 794-805. https://doi.org/10.1672/0277-5212(2007)27[794:ACONAC]2.0.CO;2

[12] Moore, H.H., Niering, W.A., Marsicano, L.J. and Dowdell, M. (1999) Vegetation Change in Created Emergent Wetlands (1988-1996) in Connecticut (USA). Wetlands Ecology and Management, 7, 177-191. https://doi.org/10.1023/A:1008434630473

[13] Robb, J.T. (2001) Indiana Wetland Compensatory Mitigation: Area Analysis. Indiana Department of Environmental Management, Indianapolis. https://www.in.gov/idem/wetlands/files/mitigation_area_analysis_report.pdf

[14] Strain, G.F., Turk, P.J. and Anderson, J.T. (2014) Functional Equivalency of Created and Natural Wetlands: Diet Composition of Red-Spotted Newts (Notophthalmus viridescens viridescens). Wetlands Ecology and Management, 22, 659-669. https://doi.org/10.1007/s11273-014-9362-6

[15] Strain, G.F., Turk, P.J., Tri, A.N. and Anderson, J.T. (2017) Anuran Occupancy of Created Wetlands in the Central Appalachians. Wetlands Ecology and Management, 25, 369-384. https://doi.org/10.1007/s11273-016-9523-x

[16] Strain, G.F., Turk, P.J., Helmick, J. and Anderson, J.T. (2017) Amphibian Reproductive Success as a Gauge of Functional Equivalency of Created Wetlands in the Central Appalachians. Wildlife Research, 44, 354-364.

https://doi.org/10.1071/WR15177 
[17] Millikin, A., Woodley, S.K., Davis, D.R. and Anderson, J.T. (2019) Habitat Characteristics in Created Vernal Pools Impact Spotted Salamander Water-Borne Corticosterone Levels. Wetlands, 39, 803-814. https://doi.org/10.1007/s13157-019-01130-5

[18] Millikin, A.R., Woodley, S.K., Davis, D.R., Moore, I.T. and Anderson, J.T. (2019) Water-Borne and Plasma Corticosterone Are Not Correlated in Spotted Salamanders. Ecology and Evolution, 24, 13942-13953. https://doi.org/10.1002/ece3.5831

[19] Clipp, H.L., Peters, M.L. and Anderson, J.T. (2017) Winter Waterbird Composition and Use at Created Wetlands in West Virginia, USA. Scientifica, 2017, Article ID: 1730130. https://www.hindawi.com/journals/scientifica/2017/1730130 https://doi.org/10.1155/2017/1730130

[20] Balcombe, C.K., Anderson, J.T., Fortney, R.H. and Kordek, W.S. (2005) Wildlife Use of Mitigation and Reference Wetlands in West Virginia. Ecological Engineering, 25, 85-99. https://doi.org/10.1016/j.ecoleng.2005.03.003

[21] Hecnar, S.J. and M'Closkey, R.T. (1998) Species Richness Patterns of Amphibians in Southwestern Ontario Ponds. Journal of Biogeography, 25, 763-772. https://doi.org/10.1046/j.1365-2699.1998.2540763.x

[22] Houlahan, J.E. and Findlay, C.S. (2003) The Effects of Adjacent Land Use on Wetland Amphibian Species Richness and Community Composition. Canadian Journal of Fisheries and Aquatic Sciences, 60, 1078-1094. https://doi.org/10.1139/f03-095

[23] Pough, F.H. (1980) The Advantages of Ectothermy for Tetrapods. The American Naturalist, 115, 92-112. https://doi.org/10.1086/283547

[24] Korfel, C.A., Mitsch, W.J., Hetherington, T.E. and Mack, J.J. (2010) Hydrology, Physiochemistry, and Amphibians in Natural and Created Vernal Pool Wetlands. Restoration Ecology, 18, 843-854. https://doi.org/10.1111/j.1526-100X.2008.00510.x

[25] Hof, C., Araujo, M.B., Jetz, W. and Rahbek, C. (2011) Additive Threats from Pathogens, Climate and Land-Use Change for Global Amphibian Diversity. Nature, 480, 516-519. https://doi.org/10.1038/nature10650

[26] Houlahan, J.E., Findlay, C.S., Schmidt, B.R., Meyer, A.H. and Kuzmin, S.L. (2000) Quantitative Evidence for Global Amphibian Population Declines. Nature, 404, 752-755. https://doi.org/10.1038/35008052

[27] Stuart, S.N., Chanson, J.S., Cox, N.A., Young, B.E., Rodrigues, A.S.L., Fischman, D.L. and Waller, R.W. (2004) Status and Trends of Amphibian Declines and Extinctions Worldwide. Science, 306, 1783-1786. https://doi.org/10.1126/science.1103538

[28] Wake, D.B. and Vredenburg, V.T. (2008) Are We in the Midst of the Sixth Mass Extinction? A View from the World of Amphibians. Proceedings of the National Academy of Sciences USA, 105, 11466-11473. https://doi.org/10.1073/pnas.0801921105

[29] Denton, R.D. and Richter, S.C. (2013) Amphibian Communities in Natural and Constructed Ridge Top Wetlands with Implications for Wetland Construction. The Journal of Wildlife Management, 77, 886-896. https://doi.org/10.1002/jwmg.543

[30] Pollet, I. and Bendell-Young, L.I. (2000) Amphibians as Indicators of Wetland Quality in Wetlands Formed from Oil Sands Effluent. Environmental Toxicology and Chemistry, 19, 2589-2597. https://doi.org/10.1002/etc.5620191027

[31] Brown, D.J., Street, G.M., Nairn, R.W. and Forstner, M.R.J. (2012) A Place to Call Home: Amphibian Use of Created and Restored Wetlands. International Journal of Ecology, 2012, Article ID: 989872. https://doi.org/10.1155/2012/989872

[32] Vasconcelos, D. and Calhoun, A.J.K. (2006) Monitoring Created Seasonal Pools for 
Functional Success: A Six-Year Case Study of Amphibian Responses, Sears Island, Maine, USA. Wetlands, 26, 992-1003. https://doi.org/10.1672/0277-5212(2006)26[992:MCSPFF]2.0.CO;2

[33] Calhoun, A.J.K., Arrigoni, J., Brooks, R.P., Hunter, M.L. and Richter, S.C. (2014) Creating Successful Vernal Pools: A Literature Review and Advice for Practitioners. Wetlands, 34, 1027-1038. https://doi.org/10.1007/s13157-014-0556-8

[34] Harkey, G.A. and Semlitsch, R.D. (1988) Effects of Temperature on Growth, Development, and Color Polymorphism in the Ornate Chorus Frog Pseudacris ornata. Copeia, 1988, 1001-1007. https://doi.org/10.2307/1445724

[35] Semlitsch, R.D., Scott, D.E. and Pechmann, J.H.K. (1988) Time and Size at Metamorphosis Related to Adult Fitness in Ambystoma talpoideum. Ecology, 69, 184-192. https://doi.org/10.2307/1943173

[36] Wilbur, H.M. and Collins, J.P. (1973) Ecological Aspects of Amphibian Metamorphosis. Science, 182, 1305-1314. https://doi.org/10.1126/science.182.4119.1305

[37] Newman, R.A. (1998) Ecological Constraints on Amphibian Metamorphosis: Interactions of Temperature and Larval Density with Responses to Changing Food Level. Oecologia, 115, 9-16. https://doi.org/10.1007/s004420050485

[38] Calderon, M.R., Almeida, C.A., González, P. and Jofré, M.B. (2019) Influence of Water Quality and Habitat Conditions on Amphibian Community Metrics in Rivers Affected by Urban Activity. Urban Ecosystems, 22, 743-755. https://doi.org/10.1007/s11252-019-00862-w

[39] McPherson, L.A. (2015) Amphibian Metamorphosis in Created and Natural Wetlands. Thesis, West Virginia University, Morgantown, 142 p.

[40] Stoler, A.B. and Relyea, R.A. (2013) Leaf Litter Quality Induces Morphological and Developmental Changes in Larval Amphibians. Ecology, 94, 1594-1603.

https://doi.org/10.1890/12-2087.1

[41] Gosner, K.L. (1960) A Simplified Table for Staging Anuran Embryos and Larvae with Notes on Identification. Herpetologica, 16, 183-190.

[42] Ter Braak, C.J.F. and Verdonschot, P.F.M. (1995) Canonical Correspondence Analysis and Related Multivariate Methods in Aquatic Ecology. Aquatic Sciences, 57, 255-289. https://doi.org/10.1007/BF00877430

[43] Snodgrass, J.W., Bryan, A.L. and Burger, J. (2000) Development of Expectations of Larval Amphibian Assemblage Structure in Southeastern Depression Wetlands. Ecological Applications, 10, 1219-1229. https://doi.org/10.1890/1051-0761(2000)010[1219:DOEOLA]2.0.CO;2

[44] Ter Braak, C.J.F. (1987) The Analysis of Vegetation-Environment Relationships by Canonical Correspondence Analysis. Vegetatio, 69, 69-78. https://doi.org/10.1007/BF00038688

[45] Balcombe, C.K., Anderson, J.T., Fortney, R.H. and Kordek, W.S. (2005) Vegetation, Invertebrate, and Wildlife Community Rankings and Habitat Analysis of Mitigation Wetlands in West Virginia. Wetlands Ecology and Management, 13, 517-530. https://doi.org/10.1007/s11273-004-5074-7

[46] Pechmann, J.H.K., Estes, R.A., Scott, D.E. and Gibbons, J.W. (2001) Amphibian Colonization and Use of Ponds Created for Trial Mitigation of Wetland Loss. Wetlands, 21, 93-111. https://doi.org/10.1672/0277-5212(2001)021[0093:ACAUOP]2.0.CO;2

[47] Martin, L.J., Rainford, S. and Blossey, B. (2014) Effects of Plant Litter Diversity, Species, Origin and Traits on Larval Toad Performance. Oikos, 124, 871-879. https://doi.org/10.1111/oik.01745 
[48] Schmutzer, A.C., Gray, M.J., Burton, E.C. and Miller, D.L. (2008) Impacts of Cattle on Amphibian Larvae and the Aquatic Environment. Freshwater Biology, 53, 2613-2625. https://doi.org/10.1111/j.1365-2427.2008.02072.x

[49] Smith, G.R. (1997) The Effects of Aeration on Amphibian Larval Growth: An Experiment with Bullfrog Tadpoles. Transactions of the Nebraska Academy of Sciences, 24, 63-66.

[50] Stevens, C.E., Paszkowski, C.A. and Scrimgeour, G.J. (2006) Older Is Better: Beaver Ponds on Boreal Streams as Breeding Habitat for the Wood Frog. The Journal of Wildlife Management, 70, 1360-1371. https://doi.org/10.2193/0022-541X(2006)70[1360:OIBBPO]2.0.CO;2

[51] Gerlanc, N.M. and Kaufman, G.A. (2005) Habitat of Origin and Changes in Water Chemistry Influence Development of Western Chorus Frogs. Journal of Herpetolo$g y, 39,254-265$. https://doi.org/10.1670/171-03A

[52] Helff, O.M. and Stubblefield, K.J. (1931) The Influence of Oxygen Tension on the Oxygen Consumption of Rana pipiens Larvae. Physiological Zoology, 4, 271-286. https://doi.org/10.1086/physzool.4.2.30151140

[53] Mann, R.M. and Bidwell, J.R. (2001) The Acute Toxicity of Agricultural Surfactants to the Tadpoles of Four Australian and Two Exotic Frogs. Environmental Pollution, 114, 195-205. https://doi.org/10.1016/S0269-7491(00)00216-5

[54] Noland, R. and Ultsch, G.R. (1981) The Roles of Temperature and Dissolved Oxygen in Microhabitat Selection by the Tadpoles of a Frog (Rana pipiens) and a Toad (Bufo terrestris). Copeia, 1981, 645-652. https://doi.org/10.2307/1444570

[55] Bidwell, J.R. (2013) Physical and Chemical Monitoring of Wetland Water. In: Anderson, J.T. and Davis, C.A., Eds., Wetland Techniques, Volume 2: Organisms, Springer, Secaucus, 325-353. https://doi.org/10.1007/978-94-007-6860-4_6

[56] Kapfer, J.M., Sandheinrich, M.B. and Knutson, M.G. (2007) Use of FETAX to Examine Acute Survival of Xenopus laevis Larvae in Water from Natural and Constructed Ponds in the Upper Midwest. Herpetological Conservation and Biology, 2, 119-125.

[57] Trebitz, A.S., Morrice, J.A., Taylor, D.L., Anderson, R.L., West, C.W. and Kelly, J.R. (2005) Hydromorphic Determinants of Aquatic Habitat Variability in Lake Superior Coastal Wetlands. Wetlands, 25, 505-519. https://doi.org/10.1672/0277-5212(2005)025[0505:HDOAHV]2.0.CO;2

[58] Batzer, D.P., Palik, B.J. and Buech, R. (2004) Relationships between Environmental Characteristics and Macroinvertebrate Communities in Seasonal Woodland Ponds of Minnesota. Journal of the North American Benthological Society, 23, 50-68. https://doi.org/10.1899/0887-3593(2004)023<0050:RBECAM>2.0.CO;2

[59] Trebitz, A.S., Brazner, J.C., Cotter, A.M., Knuth, M.L., Morrice, J.A., Peterson, G.S., Sierszen, M.E., Thompson, J.A. and Kelly, J.R. (2007) Water Quality in Great Lakes Coastal Wetlands: Basin-Wide Patterns and Responses to an Anthropogenic Disturbance Gradient. Journal of Great Lakes Research, 33, 67-85. https://doi.org/10.3394/0380-1330(2007)33[67:WQIGLC]2.0.CO;2

[60] deCatanzaro, R. and Chow-Fraser, P. (2011) Effects of Landscape Variables and Season on Reference Water Chemistry of Coastal Marshes in Eastern Georgian Bay. The Canadian Journal of Fisheries and Aquatic Sciences, 68, 1009-1023. https://doi.org/10.1139/f2011-035

[61] Houlahan, J.E. and Findlay, C.S. (2004) Estimating the "Critical" Distance at Which Adjacent Land-Use Degrades Wetland Water and Sediment Quality. Landscape Ecology, 19, 677-690. https://doi.org/10.1023/B:LAND.0000042912.87067.35 
[62] Costa, H.H. (1967) Avoidance of Anoxic Water by Tadpoles of Rana temporaria. Hydrobiologia, 30, 374-384. https://doi.org/10.1007/BF00964023

[63] Cummins, C.P. (1986) Effects of Aluminum and Low pH on Growth and Development in Rana temporaria Tadpoles. Oecologia, 69, 248-252. https://doi.org/10.1007/BF00377630

[64] Egea-Serrano, A., Relyea, R.A., Tejedo, M. and Torralva, M. (2012) Understanding of the Impact of Chemicals on Amphibians: A Meta-Analytic Review. Ecology and Evolution, 2, 1382-1397. https://doi.org/10.1002/ece3.249

[65] Vasconcelos, D. (2003) Amphibian and Vegetation Dynamics in a Restored Wetland in Maine. M.S. Thesis, University of Maine, Orono.

[66] Skelly, D.K., Freidenburg, L.K. and Kiesecker, J.M. (2002) Forest Canopy and the Performance of Larval Amphibians. Ecology, 83, 983-992. https://doi.org/10.1890/0012-9658(2002)083[0983:FCATPO]2.0.CO;2

[67] Stephens, J.P., Berven, K.A. and Tiegs, S.D. (2013) Anthropogenic Changes to Leaf Litter Input Affect the Fitness of a Larval Amphibian. Freshwater Biology, 58, 1631-1646. https://doi.org/10.1111/fwb.12155

[68] Babbitt, K.J., Baber, M.J. and Brandt, L.A. (2006) The Effect of Woodland Proximity and Wetland Characteristics on Larval Anuran Assemblages in an Agricultural Landscape. Canadian Journal of Zoology, 84, 510-519.

https://doi.org/10.1139/z06-020 